International Journal of Canadian Studies

Revue internationale d'études canadiennes
INTERNATIONAL JOURNAL OF CANADIAN STUDIES

REVUE INTERNATIONALE D'ÉTUDES CANADIENNES

\title{
The History and Current Status of the Instruction of Spanish as a Heritage Language in Canada
}

\section{Florencia Carlino}

Numéro 38, 2008

Borders, Migrations and Managing Diversity: New Mappings

Frontières, migrations et gestion de la diversité : nouvelles

cartographies

URI : https://id.erudit.org/iderudit/040817ar

DOI : https://doi.org/10.7202/040817ar

Aller au sommaire du numéro

Éditeur(s)

Conseil international d'études canadiennes

ISSN

1180-3991 (imprimé)

1923-5291 (numérique)

Découvrir la revue

Citer cette note

Carlino, F. (2008). The History and Current Status of the Instruction of Spanish as a Heritage Language in Canada. International Journal of Canadian Studies / Revue internationale d'études canadiennes, (38), 263-277.

https://doi.org/10.7202/040817ar 


\section{The History and Current Status of the Instruction of Spanish as a Heritage Language in Canada ${ }^{2}$}

Spanish as a heritage language (SHL) is a well-recognized field of study and practice in the United States ${ }^{3}$. SHL instruction targets Americans of all ages with a Hispanic or Latino family background (Valdés, G., Lozano, A. \& García Moya, R., eds. 1981; Roca, A. \& Colombi, M.C., $2003)^{4}$. While this field of study is rooted in the social, cultural, and demographic needs of the growing Latino population in the United States, the constraints on its development are imposed by the political framework which is limiting Latino immigration. Because the United States is the only country with a relevant corpus of research in the area, the study of SHL instruction in North America is usually based on the American experience. Very little is known about the Canadian SHL experience, despite the richness, complexity, and development of other heritage language educational programs in this country.

In Canada, while the development of other heritage languages has been quite noticeable over the last thirty years, SHL is still a newcomer to the heritage language field. There are few SHL programs in the Canadian provinces where Hispanics are concentrated (Ontario, Quebec, British Columbia, and Alberta). According to a study carried out in 1996, there were 402,100 people of Hispanic origin living in Canada. Of that number, $61 \%$ (i.e. 245,495 ) had Spanish as a mother tongue and only $35 \%$ (i.e., 141,640 ) used Spanish at home (Barrio Barrio et al., 2000). These data constitute the starting point for this inquiry. What has happened to the remaining $65 \%$ of Hispanic Canadians (i.e., 260,460 people) who do not use Spanish at home? Why does this happen? Do Canadian institutions provide the resources and create the conditions for Hispanic Canadians to keep their ancestral language? What causes Hispanic Canadians to stop using their native language? Are there historical reasons to explain this? Are there political or legal explanations?

The purpose of this article is to contextualize the question of the development of Spanish instruction for Hispanic Canadians in Canada, and to discern possible underlying issues of the question. The article is organized into two main sections. The first provides a very brief summary 
of the American SHL experience as a reference point for comparing and contrasting the situation in Canada. The second reviews the development of SHL within the Canadian context.

\section{SHL and its Development in the United States}

"Heritage languages" (HL) refers to languages spoken in immigrant communities. These are different from the official languages. HL speakers have acquired their language through normal family interaction. The formal acknowledgement of these languages and the beginning of $\mathrm{HL}$ instructional programs date back to the 1970 s.

Research has shown that second and third generation immigrants may easily lose their linguistic heritage if there is no specific pedagogic intervention or if the mother tongue is underused, and that this loss usually happens between the ages of 4 and 6 (Cummins, Ramos \& Lopes, 1989). The loss of the HL in immigrant families occurs when children do not interact regularly and naturally with their parents in the native language. Such interaction is necessary to counterbalance the ongoing immersion in the dominant language through school socialization, mass media interaction, and other means of non-formal and informal education.

In the United States, under the leadership of the American Association of Spanish and Portuguese Teachers (AASPT), SHL instruction started to receive special attention at the beginning of the 1970s. This development was meant to satisfy the linguistic needs of the growing Latino population (Colombi \& Roca, 2003, p. 6-7).

The Constitution of the United States has not adopted an official language because it has enshrined the principle of free speech, which is quite broad in nature. This principle allows state constitutions to legislate on matters of linguistic policy. According to the 2000 census, Hispanics are the fastest growing population group in the United States. With 35.5 million persons (i.e., $12 \%$ of the country's total population), they are now the largest minority group. These figures represent a $60 \%$ increase since the previous census. Although Spanish is the second spoken language in the United States, Latino descendants strive to adapt to the American dominant culture. This assimilation trend is evident in the decrease of the use of Spanish in public and in the loss of Spanish accents. ${ }^{5}$

The social message which promotes assimilation into the dominant language group is more evident in some states than in others. In fact, in recent years, some bilingual Spanish-English education programs were abandoned in some states, as a result of both xenophobic policies and a socially and politically hostile climate for immigrants and their educa- 
tional and social needs. The paradox is clear. On the one hand, according to the 1990 census, many new immigrants entered the United States in the 1980 s and the number of bilingual speakers increased by $40 \%$. On the other hand, the 1980s witnessed the beginning of the "English only" movement which has eroded the social achievements of the Civil Rights Movement of the last two decades (Colombi \& Roca, 2003, p. 6). The battle is not over and today's social and political scenarios offer contradictory signs. California, for example, where a third of the population is of Latino origin, approved Proposition 227 against bilingual education in 1998. In the mid-1980s, California and other states with significant Latino populations, such as Arizona and Florida, had adopted English as their official language.

\section{Canada: Barriers and Possibilities for the Development of SHL}

Canada offers a very different context for the development of formal SHL instruction than the United States. It presents a particularly complex language scene; in this country there are three types of language-learning environments:

- the official languages (English and French);

- the different heritage languages spoken by minority communities (Chinese, Italian, German, Cantonese, Punjabi, Spanish, Portuguese, Polish, Arabic, Tagalog, Ukrainian, Dutch, Vietnamese, Greek, etc.);

- the Aboriginal languages (Ojibway, Cree, Inuktitut, Athapaskan, Dakota, Salish, etc.).

In addition, the popularity of French immersion programs for the Anglophone population in Canada makes this country a special laboratory for language teaching. Because of all these special features, it is natural to believe that SHL has a huge potential. However, the reality contradicts this assumption. My analysis will show that there are possibilities for, and barriers to the development of educational programs designed to offer Spanish as a minority language in Canada. Among the possibilities, I will comment on the Canadian political and legal framework and I will summarize the main aspects of other existing HL programs, as well as the growing popularity of courses in Spanish as a foreign language. Among the barriers, I will refer to historical contradictions and tensions which contribute to prejudices and misconceptions. Finally, I will address the issue of the availability of resources. 
The Canadian Political and Legal Framework: Diversity, Bilingualism, and Multiculturalism

In Canada, there is a political and legal framework which promotes bilingual and multicultural education, as well as cultural diversity for minorities. This framework has official (both federal and provincial) as well as popular support. This situation is in sharp contrast with that of the United States where attacks against bilingual education have been evident in some states since the $1980 \mathrm{~s}$. The historical roots of this issue can be traced back to the following situation:

Bilingualism has not yet enjoyed great prestige in this country. [...] [W] hile in many other countries, one is not considered educated if one is not bilingual, in the United States to be bilingual means to be uneducated. This position is not surprising given the history of the United States and its immigrant background. For a long time the myth of the melting pot enjoyed wide support and there were many who echoed opinions, such as that expressed by one researcher (Jordan, 19216) who argued that it was not sufficient for an immigrant to learn English. He must use it at home. (Valdés, Lozano \& García-Moya, 1981, Introduction, p. ix).

Some of the differences between Canada and the United States with respect to HL policies have to do with the composition of each society, the value and meaning of immigration and diversity, and the educational and linguistic policies put into practice in each case.

Canada is a bilingual country; English and French are the two official languages. However, official bilingualism does not mean that all Canadians are bilingual citizens. ${ }^{7}$ English remains the majority language of the Canadian population (59.1\%). Francophones, concentrated mainly in Quebec, account for $22.9 \%$ of the population. According to the 2001 Census, only $17.7 \%$ of the population use both official languages on a regular basis.

Canada is also a confederation of ten provinces and three territories. Each province adopts its own educational and linguistic policies. Quebec is the only officially francophone province and New Brunswick is the only officially bilingual province. The other eight provinces have a majority of English speakers, although French and other minority languages are also spoken. In each province, the public school system provides the option of French immersion education ${ }^{8}$ to English-speaking students in elementary and secondary schools. Public French immersion programs have existed since the 1960 s in Canada where they have a very good reputation. They are cited internationally as an example of effective bilingual education. 
The educational policies regarding early and late French immersion programs directed to the anglophone and immigrant populations have had the benefit of encouraging a greater awareness of the country's official language duality. In addition, it has given rise to a new attitude towards language learning and has alerted the public to the fact that unilingualism can be a disadvantage (Mannavarayan, 2002, p. 25).

In addition, Canada is a multicultural society which receives significant numbers of legal immigrants from all over the world every year. Unlike the United States, Canada has practically no illegal immigration. Active immigration policies attempt to offset the low fertility rate and increase the labour force.

The legislative framework that fosters Canada's approach to diversity has been expanded over time. In 1969, the Official Languages Act established English and French as the official languages of Canada. The Act encouraged federal institutions and agencies to contribute to "the encouragement of cultural diversification within a bilingual framework." To reflect the changing social, cultural, economic, and political profile of the country, recommendations addressing the needs of non-English and nonFrench groups included in the Act led to the proclamation of the Canadian Multiculturalism Policy in 1971. This policy has contributed to building an inclusive Canada by supporting linguistic, ethnocultural and ethnoracial pluralism within Canada's commitment to individual rights. In July 1988, The Multiculturalism Act was approved unanimously by both Houses of Parliament. This represents a step towards urging federal institutions to respect Canada's multicultural character and reflect the cultural, ethnic, and racial diversity of Canadian society. The Act explicitly recognizes the value of the various linguistic communities, and their contribution to modern Canada. It also favours the preservation of languages other than English and French as an important part of the Canadian heritage. As a result, in Canada there are now two official languages but not a single official culture.

\section{The Development of HL Programs}

In the last 35 years, most Canadian provinces have developed different types of multilingual publicly funded programs. In these programs, minority language instruction has occupied a focal place. Unlike most American bilingual instruction, which pursues assimilation and which is designed to remedy the presumed low academic achievements of the targeted population, the general goals of the Canadian programs are to stimulate the vitality of ethnic communities and to enrich children's academic experience. None of these programs target college students. Chart 1 summarizes the HL programs in Canada. ${ }^{9}$ 


\section{Chart 1: Heritage Language Programs in Canada}

REGION/ PROVINCE

The Prairies region

(Alberta, Manitob

\& Saskatchewan)
PUBLIC

NON PUBLIC FUNDED BY LANGUAGES TAUGHT

Public

FUNDED BY
The provincial
government

Two-way Ukrainian-English.

Ukrainian

Other bilingual programs:

English and

Mandarin/Polish
Hebrew/ Yddish/ Arabic/

OTHER FEATURES

\section{COMMENTS}

The school boards in the city of Edmonton (Alberta) was the first to offer these programs in 1971.

The three provinces have very active HL associations which train teachers and are in close contact with the provincial educational authorities.

\begin{tabular}{|c|c|c|c|c|}
\hline \multirow[t]{3}{*}{ Ontario } & Public & $\begin{array}{l}\text { The provincial } \\
\text { government }\end{array}$ & $\begin{array}{l}\text { Several heritage languages } \\
\text { including Spanish. }\end{array}$ & $\begin{array}{l}\text { These are after school } \\
\text { programs. }\end{array}$ \\
\hline & & & & $\begin{array}{l}\text { Meeting up to five hours } \\
\text { a week. }\end{array}$ \\
\hline & & & & $\begin{array}{l}\text { HL instruction is not allowed } \\
\text { as part of the regular } \\
\text { curriculum. }\end{array}$ \\
\hline
\end{tabular}

\begin{tabular}{lll}
\hline Quebec & $\begin{array}{l}\text { Two different } \\
\text { public bilingual }\end{array}$ & $\begin{array}{l}\text { a. The Quebec } \\
\text { Ministry of }\end{array}$ \\
& programs. & Education.
\end{tabular}

a. 11 languages offered,
including Greek, Portuguese,
Spanish, Italian, Arabic,
The creation of these programs

in 1977 was a response to

increasing immigration,

especially in Toronto. At that time, $50 \%$ of the students

attending Toronto School

Board schools came from non-English-speaking families

The Ontario HL Association holds meetings only once in a while.

$\begin{array}{ll}\text { a. The HLs are taught at the } & \text { a. The program is known as } \\ \text { elementary level for } 30 & \text { PELO (Programme } \\ \text { minutes per day. } & \text { d'enseignement des langues } \\ \text { Teachers are not specially } & \text { d'origine). It was created in } \\ \text { trained to teach HL. They are } & 1978 .\end{array}$
usually HL native speakers. 


\begin{tabular}{|c|c|c|c|c|c|}
\hline & & $\begin{array}{l}\text { b. The Quebec } \\
\text { Ministry of Cultural } \\
\text { Communities and } \\
\text { Immigration. }\end{array}$ & $\begin{array}{l}\text { b. Several heritage } \\
\text { languages. }\end{array}$ & $\begin{array}{l}\text { b. Saturday and Sunday } \\
\text { instruction for students } \\
\text { from } 6 \text { to } 17 \text { years old. }\end{array}$ & \\
\hline British Columbia & $\begin{array}{l}\text { Private programs } \\
\text { which operate } \\
\text { outside of school } \\
\text { hours. }\end{array}$ & $\begin{array}{l}\text { Different sources of } \\
\text { funding including } \\
\text { the federal } \\
\text { government. } \\
\text { Provincial governmen } \\
\text { does not have a major } \\
\text { investment in HL edu }\end{array}$ & $\begin{array}{l}26 \text { languages are taught, } \\
\text { including Spanish and several } \\
\text { Asian languages. Bilingual } \\
\text { programs such as Russian- } \\
\text { English and Hebrew-English } \\
\text { are offered. } \\
\text { it } \\
\text { cation. }\end{array}$ & $\begin{array}{l}\text { Provincial government allows } \\
\text { school boards to offer HL } \\
\text { instruction. }\end{array}$ & Operated from 1986 to 1987. \\
\hline $\begin{array}{l}\text { The Atlantic } \\
\text { Provinces } \\
\text { (Nova Scotia, } \\
\text { New Brunswick, } \\
\text { Newfoundland, } \\
\text { Prince Edward } \\
\text { Island). }\end{array}$ & $\begin{array}{l}\text { Non-public } \\
\text { programs are } \\
\text { offered through } \\
\text { complementary } \\
\text { schools. }\end{array}$ & $\begin{array}{l}\text { No support from } \\
\text { provincial } \\
\text { governments. } \\
\text { a. Different sources } \\
\text { of funding including } \\
\text { the federal } \\
\text { government. } \\
\text { b. \& c. Self supported. }\end{array}$ & $\begin{array}{l}\text { a. Arabic is the most } \\
\text { popular HL offered. } \\
\text { b. In Nova Scotia (Cape } \\
\text { Breton) there was a } \\
\text { Gaelic playgroup. } \\
\text { c. In Nova Scotia (Halifax), } \\
\text { there was a free Spanish } \\
\text { program. }\end{array}$ & $\begin{array}{l}\text { c. The program targeted to } \\
\text { children } 4 \text { to } 6 \text {. It was run at } \\
\text { a local university by a member } \\
\text { of the Spanish faculty. }\end{array}$ & a. Operated from 1986 to 1987. \\
\hline
\end{tabular}


Although the information presented in the chart is not exhaustive, it provides evidence of the complexity, variety, and development of HL programs in different regions/provinces in Canada. This panorama is not complete if we do not mention the existence of trilingual non-public programs in most major Canadian cities (Cummins, 1983, p. 9-10). These programs involve the two official languages (French and English) as well as a third language, such as Hebrew or Italian.

One interesting aspect of the HL programs in Canada is the lack of political identification of both promoters and detractors. While in most European countries the promotion of $\mathrm{HL}$ and minority dialects is usually the work of leftist social activists, in Canada the linguistic and educational policies that support or hinder the development of HL education do not have a unique political signature. For instance, in the Prairies region, which has been a pioneer and very active in this field, these policies have been supported by two opposing political parties: the Conservative Party and the New Democratic Party (which represents the bulk of left wing voters). By contrast, in Toronto both the Liberal and the Conservative parties have denied support for these policies (Cummins \& Danesi, 1990, p. 6-8).

\section{Historical Contradictions and Tensions}

From a historical perspective, Troper (1979) argued that the celebration of the multicultural character of Canadian society evolved after the Second World War as a means to fill a national identity vacuum. According to Troper, the celebration of Canadian multiculturalism has a psychological and political purpose: to foster integration among AngloCanadians and differentiate them from Americans. In fact, Canadians use the "Canadian mosaic" metaphor when speaking of Canadian cohesiveness. John Murray Gibbon (1938) was the first to use the term "mosaic" to describe Canadian society. He announced a new perspective about immigration that was to reshape Canadian immigration policy in the latter part of the twentieth century, especially with the multicultural policy adopted in the 1970s, and refined in the 1980s with the passing of the Canadian Multiculturalism Act. In his view, the idea of a mosaic allowed each cultural group to retain a particular identity and still contribute to the nation as a whole. The mosaic metaphor was in contrast to the "melting pot", a popular metaphor for the more assimilationist American approach to immigration.

The meanings associated with the "Canadian mosaic" metaphor contrast with the ones related with the "melting pot", which is the image used in the American political discourse. The American metaphor emphasizes the assimilation because the pot (i.e., the whole society) 
melts, dilutes, and absorbs the parts (Troper, 1979; Harney \& Troper, 1975; Cummins \& Troper, 1985, quoted by Cummins \& Danesi, 1990, p. $2,9 \& 13)$.

Troper also holds that the Canadian idealization of the value of immigration is a myth. Cummins and Danesi go even further in arguing that the celebration of multiculturalism by Canadian society is only a superficial facade which hides the history of racist and discriminatory institutional structures. They also suggest that this historical legacy has negatively impacted public support of linguistic resources for the development of minority languages (Cummins \& Danesi, 1990). ${ }^{10}$ Specifically, in relation to the HL field, the official and popular multicultural discourse has had a positive, although superficial, impact on Canadian society, for example, the massive acceptance of ethnic food by average Canadians and the public celebration of ethnic feasts and traditions in elementary schools. These aspects are not necessarily conducive to the adoption and application of linguistic policies which favour HL preservation.

However, it is also fair to highlight that multiculturalism has deeply affected Canada's institutional structures. The complexity and richness of the HL programs described in Chart 1 and discussed above show the interest of $\mathrm{HL}$ communities in maintaining their own language, as well as the involvement of the federal and provincial governments in such projects. These are excellent signs that point to a general tendency in Canada to overcome its discriminatory past.

\section{Spanish as an Emergent Language}

The importance of the Spanish language in Canada, as in the United States, has grown significantly as evidenced by the number of people who speak it as a mother tongue and by the number of citizens who want to study it as a second or foreign language. Chart 2 shows that Canadians who speak Spanish as a mother tongue are concentrated in Ontario, Quebec, British Columbia and Alberta. 


\section{Chart 2}

Canadian Population Declaring Spanish as a Mother Tongue, by Province and Territory (Statistics Canada, 2001)

$\begin{array}{lr}\text { CANADA } & 245,495 \\ \text { Ontario } & 111,690 \\ \text { Quebec } & 70,095 \\ \text { British Columbia } & 28,240 \\ \text { Alberta } & 19,820 \\ \text { Manitoba } & 5,210 \\ \text { Saskatchewan } & 1,970 \\ \text { Nova Scotia } & 700 \\ \text { New Brunswick } & 510 \\ \text { Yukon Territory } & 75 \\ \text { Northwest Territories } & 60 \\ \text { Newfoundland and Labrador } & 55 \\ \text { Prince Edward Island } & 55 \\ \text { Nunavut } & 15\end{array}$

Several factors have contributed to the growth of Spanish in Canada. These include, 1) the increasing immigration from Hispanic countries, 2) the existence of a legal framework (NAFTA) designed to promote economic, commercial, and educational relations between Canada and Mexico, 3) the already discussed multicultural character of Canadian society, 4) Canadians' awareness of Hispanic culture gained through inexpensive tourist packages to the Caribbean and other parts of the Hispanic world, and 5) the visibility of the Spanish language in the media and particularly through the internet.

In the past few years, there has been increasing interest in studying Spanish as a foreign language. It has become the third language taught, after English and French, and the first studied international language studied at school. According to research carried out by the Spanish Embassy in Canada, interest in Spanish as a foreign language grew 300\% between 1990 and 2000 (Barrio Barrio et al., 2000, p. 3). The francophone population has contributed the most to this growth. For example, in Quebec, between 1991 and 1996, 31.15\% of the population was able to have a conversation in Spanish. During the same period in Quebec, Spanish as a spoken language increased at a rate 30 times greater than Italian which, at the time, was the third spoken language in that province (Barrio Barrio et al., 2000, p. 5-6).

If we focus on the curriculum, interest in Spanish as a foreign language is especially evident in high school. In the private and public school systems across Canada, $15 \%$ of students in elementary school 
chose Spanish, ranking it sixth after Italian, Portuguese, Polish, Arabic, and Chinese. In high school, Spanish is the first foreign language, studied by $45 \%$ of students, followed by Chinese, German, Japanese, Italian, and other languages (Barrio Barrio et al., 2000, p. 11). ${ }^{11}$ The provincial governments of British Columbia, Manitoba, New Brunswick, Quebec, and Saskatchewan have shown an interest in including Spanish as part of the curriculum in elementary and secondary schools. (Barrio Barrio et al., 2000, p. 12-14).

\section{The Resource Issue}

After a quick glance at Chart 1 , it is evident that despite the value of HL programs in general, provincial investment in SHL programs remains weak in most Canadian provinces. Quebec, Ontario, British Columbia, and Nova Scotia have created different types of SHL instructional programs. In Quebec, where there is an important concentration of Hispanic Canadians who are considered potential supporters of the province's official language policies, attention to the cultural needs of this minority group by the provincial authorities may in fact result in support of these policies. In Ontario, the debate about the advantages and disadvantages of HL teaching has been very lively among taxpayers. Defenders of minority language instruction were not successful in preventing the province from restricting the development of $\mathrm{HL}$ as part of the official curriculum. In British Columbia, investment in HL programming has not been significant although the federal government has provided some support for HL education. Finally, the Nova Scotia experience in SHL is particularly interesting for two reasons: It shows the local interest in Spanish by the Hispanic community in a province where there are few Hispanics (around 1,000 people). It provides an example of a university connecting with the community. Nevertheless, the SHL program did not receive any official support and the number of students enrolled was not significant. ${ }^{12}$

At this point in time, with the exception of Quebec, provincial support for SHL program development has not been very significant. The Ministry of Education of Spain is a possible source of financial and pedagogical support for these programs. Recently, after assessing the potential for Spanish language instruction in Canada, the Spanish Ministry of Education established a new policy aimed at promoting the Spanish language and culture. The first steps of this policy are: 1) signing mutual cooperation agreements between the Spanish Ministry of Education, Culture and Sport and some Canadian school boards, academic centers and universities, and 2) sending technical advisors to Canada to work on teacher training, conference organization and academic exchange promotion (Barrio Barrio et al., 2000, p. 3-4). 
Finally, with the exception of the small program in Nova Scotia, there is a lack of coordination between existing SHL and the regular research and training activities of university centers and academic departments such as Education, Linguistics, Spanish, and Modern Languages. The resources generated by academia (knowledge, technology, qualified human resources, and instructional materials) have not yèt been linked to SHL instruction in cities such as Montreal or Toronto, where the academic and research sophistication is remarkable and the demand for SHL is important. So far in Canada, there are no concrete signs of cooperation between research and training institutions, and program delivery agencies, as is the case for some very interesting programs in the United States ${ }^{13}$.

\section{Conclusion}

In Canada, the development of several heritage language instructional programs has progressed in the last thirty-five years. SHL, in particular, still seems to be underdeveloped with only a few instructional programs operating, especially in Quebec, Ontario, British Columbia, and, more recently, in Nova Scotia.

While Spanish has received less academic and political attention than other heritage languages, it is evident that its development has great potential. This potential comes from different sources. First, Canada is a multicultural and multilingual society, open to immigration from different parts of the globe, and immigration from Hispanic speaking countries continues to be welcomed. Second, Spanish as a foreign language has become a very popular school subject chosen by a growing number of anglophone and francophone Canadians in the last 15 years. Third, the social, economic, cultural, and practical utility of Spanish is evident in the current globalized world. Finally, Spanish authorities have recently demonstrated political interest and a willingness to financially support the dissemination of their language in Canada.

Despite all these elements favourable to the expansion of Spanish in Canada, the official (provincial and federal) resources to support SHL programs are still very scarce and the Hispanic Canadian community does not seem to be organized enough to change the situation. The somewhat systematic attempts to teach Spanish to the Latino Canadians have been left to amateurs and to the efforts of native Spanish-speaking volunteer teachers who lack specific pedagogic training. In addition, there are practically no formal or even informal connections between the few SHL initiatives and university departments or programs in the areas of Spanish, Linguistics, Modern Languages, or Education. 
Unless Spanish for Spanish speakers is considered a serious research subject or a praxis that requires pedagogical specialization, as well as financial and administrative support - as in the United States - it is very unlikely that the current development of SHL will improve in Canada, in spite of a huge potential.

\section{Notes}

1. Professor, Sault College, Sault Ste. Marie, Ontario, Canada.

2. I am very thankful to Dr. Marie-Lucie Tarpent (professor at Mount Saint Vincent University) for her rigorous comments regarding the content and the edition of this article.

3. In the United States, this field is also called "Spanish for bilingual speakers," or "Spanish for native speakers."

4. The question of what is the appropriate term (Hispanic or Latino) remains open. The term Latino is viewed as the one preferred by older immigrants in the United States who identify themselves with the Latin American culture. Hispanic, on the other hand, is the preferred term used by the younger generations of immigrants who expect to be assimilated into the United States, and it is also the term employed by the United States federal government in census and political documents. For these reasons, and to leave the question open, in this article, I will use both terms to refer to the first, second, and third generations of immigrants of Latin American or Spanish descent living in Canada or the United States.

5. Current films, such as Real Women Have Curves (Brown \& Cardoso, 2002), serve as very good illustrations of the linguistic, cultural, educational, and social challenges faced by Hispanic American families in their need to assimilate to the American way of life.

6. The authors refer to Jordan, R. H. (1921). "Retention of foreign language in the home." Journal of Educational Research, 3, p. 35-42.

7. [...] [O]fficial labels like 'monolingual', 'bilingual', or 'multilingual' have little to do with the actual distribution of bilingualism. Such labels are better understood as political statements of attitude towards minority groups rather than as statistical indications of the degree of bilingualism amongst the country's inhabitants (Harding-Esch \& Riley, 2003, p. 31).

8. Immersion programs "consist of teaching all or part of the school subjects through the medium of a language that is not usually spoken at home or in the social environment of the student" (Mannavarayan, 2002, p. 25). Complete immersion in a new linguistic and cultural environment during a considerable period of time is meant to compensate for the lack of exposure to that language and culture by the target population. In Canada, French immersion may be early (as soon as the child enters elementary school) or late (beginning in grade seven).

9. Most of the information about the public heritage language programs summarized in Chart \# 1 was taken from three main sources: Cummins (1983), p. 4-17; Cummins \& Danessi (1993), chapter 3, and Fleury (2000), p. 15-17. The descrip- 
tion of the Atlantic Provinces has other sources of information which are referred to in the footnotes.

10. Several historical situations provide evidence of the existence of racist structures, according to the authors of this thesis. Among these, the authors comment on the repression of the indigenous languages and cultures through residential schools until the middle of the twentieth century; the prohibition of the Gaelic language in schools in Cape Breton (a region largely populated by immigrants from Scotland), including physical punishment for those who violated the prohibition; the segregated schools for coloured people in the Atlantic Provinces and Ontario, which prevailed during the nineteenth and the twentieth centuries, until 1965 when the last one was closed; a national policy which was reluctant to accept Jews before and after the Second World War; the discriminatory treatment of the JapaneseCanadians during the War; and the poor and unfair conditions in Canadian indigenous communities. (Cummins \& Danesi, 1990, p. 9-10).

11. This study provides the only available source of information about interest in Spanish language in Canadian society. However, the data do not indicate how many of the students who choose to study Spanish at school are Hispanics or have a Hispanic background themselves. In this study, the category "foreign language" is used from the perspective of the curriculum rather than from the perspective of the students.

12. The author of this article launched and coordinated this voluntary, free, and pilot program in Halifax as part of her external service responsibilities at the university. Although the target community responded very favourably to this initiative, the lack of a more formal structure made it difficult to sustain the program over time.

13. A very good example of this cooperation is the Doctoral Lab for Linguistic \& Cultural Diversity operated by the Colorado Consortium of Dual Language Program. The Consortium (which includes 12 schools) "provides doctoral students with access to a wide variety of Dual Language (Spanish-English) schools, communities and programs. [...] The Lab's relationship to the Consortium is one of being the action research site." The Consortium benefits from the Lab because "it provides ongoing reflection with analysis and synthesis to fine-tune the programs."

\section{Bibliography}

Barrio Barrio, J. F., dir. et al. (2000). Situación del español y actuaciones de la Consejeria de Educación y Ciencia en Canadá. Ottawa: Oficina de Educación y Ciencia, Embajada de España.

Brown, E. \& G. LaVoo (producer) \& P. Cardoso (director) (2002). Real Women have Curves. [Motion Picture] United States: HBO.

Colombi, M. C. \& A. Roca. (2003). "Insight from Research and Practice in Spanish as a Heritage Language." In Roca, Ana \& M. Cecilia Colombi, eds. (2003). Mi Lengua. Spanish as a Heritage Language in the United States. (pp. 1-21) Washington D.C.: Georgetown University Press. 
Cummins, J. 1993. "The Research Basis for Heritage Language Promotion." In Danesi, M., K. McLeod \& S. Morris, eds. (1993). Heritage Language and Education. The Canadian Experience. New York: Mosaic Press.

Cummins, J. 1983. Heritage Language Education. A Literature Review. Toronto: The Minister of Education, Ontario, Queen's Park.

Cummins, J. \& M. Danesi. (1993). Heritage Languages. The Development and Denial of Canada's Linguistic Resources. Montreal: La maîtresse d' école inc.

Cummins, J., J. Ramos \& J. Lopes. (1989). The Transition from Home to School: A Longitudinal Study of Portuguese-Speaking Children. Unpublished research report, OISE.

Cummins, J. \& Troper, H. (1985). "Multiculturalism and Language Policy in Canada". In Cobarrubias, J., ed. (1985). Language Policy in Canada. Current Issues. Quebec: CIRB/ICRB.

Doctoral Lab for Linguistic \& Cultural Diversity. (2007). Accessed from: http://carbon.cudenver.edu/ sshannon/pdfs/The $\% 20$ Doctoral $\% 20 \mathrm{Lab} \% 20$ for $\% 20$ Ling.pdf on June.

Gibbon, J. (1938). Canadian Mosaic: The Making of a Northern Nation. Toronto: McClelland \& Stewart.

Harney, R. \& Troper, H. (1975). Immigrants. A Portrait of Urban Experience 18901930. Toronto: Van Nostrand Rheinhold.

Roca, A. \& M. C. Colombi, eds. (2003). Mi Lengua. Spanish as a Heritage Language in the United States. Washington D.C.: Georgetown University Press.

Statistics Canada. 2005. From: http://www.statcan.ca/, July 24.

Troper, H. (1979). An Uncertain Past. Reflections on the History of Multiculturalism. TESL talk, 10, 7-15.

U.S. Census Bureau, Population Division, Ethnic and Hispanics Statistics Branch. (2000). "Hispanic or Latino Origin for the United States, Regions, Divisions, States and for Puerto Rico: 2000 (PHC-T-10)." From: www.census.gov/population/www.cen2000/phc-t10.html, Oct. 32002.

Valdés, G., A., Lozano \& R. García-Moya, eds. (1981). Teaching Spanish to the Hispanic Bilingual. Issues, Aims, and Methods. New York: Teachers College Press. 